\title{
Impact of Labor Mobility on Economic Growth: A Comparative Study between Egypt and Vietnam
}

\author{
Prof. Doaa M. Salman \\ October University for Modern sciences and Arts University \\ *Corresponding author: Prof. Doaa M. Salman, dsalman@msa.edu.eg
}

\begin{abstract}
This paper will discuss how labor mobility accelerates economic growth based on a comparative study between Egypt and Vietnam during the period of 2009 to 2019 from the Index of Economic Freedom. This paper is based on analyzing the four main pillars of economic freedom. Using the Heritage Foundation to assess the labor mobility in both Egypt and Vietnam, both countries were considered as mostly unfree with an overall score of 52.5\% with a world rank of 144 and an overall score of $55.3 \%$ with a world rank of 128 , respectively. Lastly, this paper will investigate, propose, and recommend ways for Vietnam and Egypt to accelerate their growths via restructuring the labor market during the period of 2008 till 2018.
\end{abstract}

Keywords: Labor mobility; Pillars of growth; Economic freedom

Publication date: August 2021; Online publication: August 30, 2021

\section{Introduction}

According to demographics provided by the Heritage Foundation, both Egypt and Vietnam had different scores in terms of their pillars of growth. There were 12 pillars involved, and each one gave a rather different score than the other. The overall score shows that Egypt was substantially higher than that of Vietnam except during 2018 to 2019. However, according to the Heritage Foundation, Vietnam ranked higher than Egypt. The reason behind such decrease is that Egypt has governmental presidency issues, and its economy is in a bad state, in which they were trying to recover and are still trying to this day. This may have had an impact on its overall rank one way or the other. The first pillar of growth is property rights, and according to the Heritage Foundation, Egypt had a higher score from 2009 to 2016 whereas Vietnam had a higher score from 2017 to 2019. In terms of judicial effectiveness, Egypt scores were higher than Vietnam during those 3 years. Government integrity had many fluctuations, but Egypt had the upper hand in most years. Vietnam displayed better scores in terms of tax burden, government spending, and fiscal health. On the other hand, Egypt displayed a higher score in business freedom than that of Vietnam whereas Vietnam had the upper hand in terms of labor, monetary, and trade freedom. Lastly, Egypt's scores were higher than those of Vietnam in terms of investment and financial freedom.

Egypt is situated in Africa, which is a home to 100 million inhabitants, and it is ranked as the $14^{\text {th }}$ most inhabited country. Egypt has its own currency, which is the Egyptian Pound. Not only that, Egypt became one of the most egalitarian countries after the January 25 Uprising, but with some discrepancies throughout the years ${ }^{[1]}$.

Egypt is ranked as the $68^{\text {th }}$ in exporting and $49^{\text {th }}$ at importing goods. Mineral and chemical products are considered to be Egypt's main imports, while natural gas and non-petroleum products, such as readymade clothes, cotton textiles, and medical products are its main exports ${ }^{[2]}$.

Vietnam is positioned in Asia, and it shares a border with China at its north with Cambodia and Laos at its west. It is ranked as the $15^{\text {th }}$ most occupied country in the world with 97 million residents. The 
Vietnamese Dong is considered as the Vietnamese sole currency. Vietnam is ranked as the $27^{\text {th }}$ country in exports and $25^{\text {th }}$ in imports. Telephones, mobile phones, computer, and electrical products are Vietnam's main exports, while integrated circuits, refined petroleum, and electrical parts are its top imports ${ }^{[3]}$.

This paper is divided into various sections starting with the abstract, then the introduction, subsequently, a literature review, which consists of an empirical analysis and a theoretical background. Thereafter, there will be a discussion on the four main pillars, which play an integral role in the economic development of Egypt and Vietnam. The rule of law comes first, which tackles property rights, government integrity, and judicial effectiveness, followed by the government size which discusses about government expenditure, fiscal health, and tax burden. Subsequently, the regulatory efficiency that debates on business freedom, monetary, and labor freedom. Finally, the open markets, which tackle trade freedom, financial freedom, and investment freedom. Lastly, a conclusion, which wraps and summarizes the significant findings of which country is better, followed by recommendations for both countries.

\section{Literature review}

\subsection{Theoretical background}

In 1776, the Classical school leader, Smith, suggested that economic growth mainly results from the division of labor. Division of labor aids in increasing the productivity of labor and per capita earnings. Nevertheless, many economists relied on the philosophy of division of labor. With the division of labor, there is a connection with the industry which aids in labor, by increasing or promising wages, which in return, escalate efficiency. Marshall, in 1890, clarified that economic growth relies on the division of labor. In Book IV, he talked about the four factors of production, which are land, labor, organization, and capital.

Schumpeter, in 1911, established that industrialization upsurges the economic growth in a nation. Such industrialization would need products and advancements in technology, etc., thus leading to efficiency and employment, and in return, the economy would prosper. According to the neoclassical model of Swan (1956), this philosophy states that increasing the capital or labor causes a diminish in marginal returns due to the fact that effects occur for a short period and a have a small impact on the economic growth. In order to raise the economic growth, higher GDP (gross domestic product) must be the target and investment as well.

In 1962, Adam Smith assumed that there is mobility of labor among diverse jobs and that the labor market is perfectly competitive. He comprehended that there must be an inertia in order for migration to transpire. In 2000, he reflected poverty to be the main pushing force in the process of migration. Whenever a worker cannot nourish himself or his family along with the regulations or restrictions, it leaves the laborer with 4 choices: to relocate, consent to aid granted by his town, rob people and become a criminal, or become a parish.

\subsection{Empirical analysis}

Business freedom speaks about the absence of inclusive burden of regulation on the government effectiveness in administrative procedures. Conversely, labor freedom shows various parts of the regulatory and lawful system in the labor market of a nation. It clarifies guidelines in regard to minimal wages, laws repressing cutbacks, and quantifiable regulatory burdens on procuring, hours, etc.

Monetary freedom characterizes price stability or strength with a set of price controls whereby both price controls and inflation adjust the market. Almost certainly, government guidelines on labor as well as business and money markets may affect the economic development and have an impact on labor mobility. As theory states, overwhelming regulatory burdens implement high transaction costs on organizations and likely misshape rivalry (and in this way, lower productivity) by including entry barriers in specific 
enterprises ${ }^{[4]}$. Such guidelines potentially influence monetary exercises and, in this way, development, altogether. Contrasted with the normal, organizations in developing nations experience multiple times more difficult guidelines than those of more extravagant nations concerning administrative expenses, and multiple times bigger bureaucratic deferrals ${ }^{[5]}$.

At that point, the economic growth impact would be bound to drop down considerably in developing nations because of the unbending industry guidelines. Be that as it may, discussion remains with respect to the association of industrial relations and the impact of labor market guidelines on financial development [6-8].

In regard to inflationary and money related approaches and results, Briault ${ }^{[9]}$ and Barro ${ }^{[10]}$ took note that it is by all accounts that inflation, at any rate at significant levels, is disruptive to financial development. A high inflation is expected to be the outcome of temperamental money related approaches. Along these lines, hypothetically, it will in general erode the benefit of redistributing salary and investment funds from recipients to borrowers. Consequently, influencing leasers' enthusiasm to credit or loan cash. Similarly, long-standing money related speculations might be discouraged if expansion creates uncertainty concerning future payoffs ${ }^{[9]}$.

\section{Overview of the Economic Freedom Index in both Egypt and Vietnam}

According to the Economic Freedom Index, in 2009 to 2019, Egypt and Vietnam were fluctuating but mostly unfree. Egypt's scores were higher than those of Vietnam throughout the years except in 2019. In 2008, Egypt had a lot of investments and innovation going on in the country, which resulted in its overall score to peak during this period. However, as time passed, the scores deteriorated. Despite that Egypt's scores were higher than those of Vietnam, most of the time, the scores of both countries are close to each other.

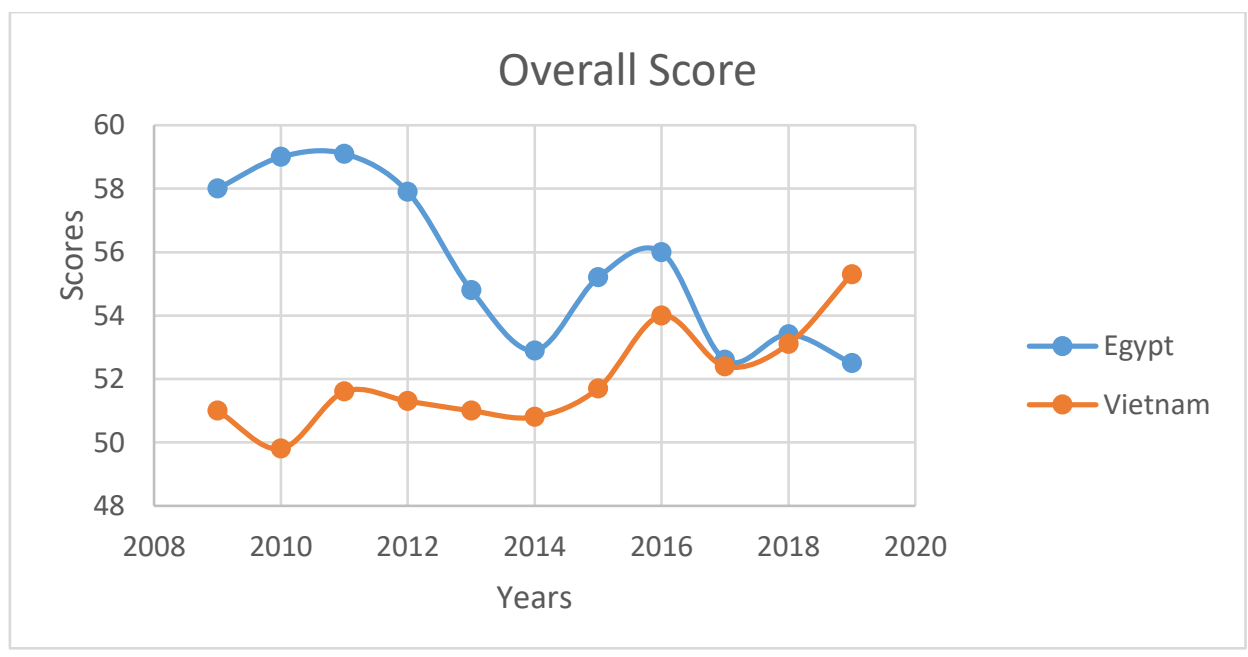

Figure 1. Overall score between Egypt and Vietnam (2009-2019)

Source: Heritage Foundation - 2019 Index of Economic Freedom

Egypt ranked $144^{\text {th }}$ according to the Economic Freedom Index with a score of $52.5 \%$ and was recognized as mostly unfree ${ }^{[11]}$.

Vietnam ranked $128^{\text {th }}$ according to the Economic Freedom Index with a score of $55.3 \%$ and was also recognized as mostly unfree ${ }^{[11]}$. 


\section{Rule of law}

Property rights, the first pillar for assessing the rule of law, reflect the rights that people possess in terms of having the rights for private properties with certain laws that reinforce and secure these properties. Nevertheless, whenever there is distress in terms of property, the economic freedom index displays that the higher the score, the lower the poverty in a specific nation.

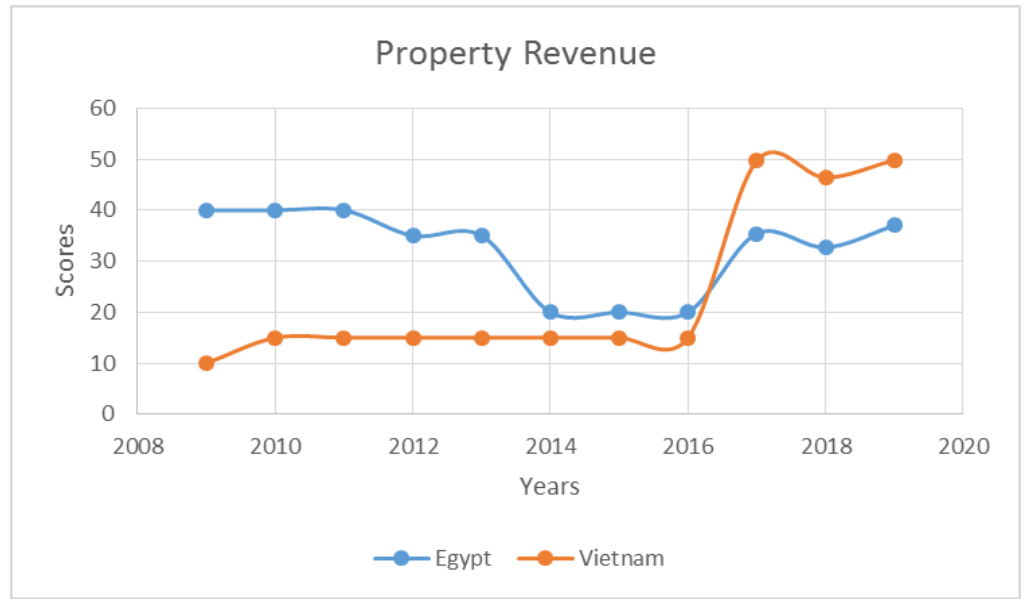

Figure 2. Property rights in Vietnam and Egypt (2009-2019)

Source: Heritage Foundation - 2019 Index of Economic Freedom

According to the graph, the property rights of the Vietnamese were following a straight line from 20112015 until in 2016, they increased drastically to around 50\%. The reason behind this drastic change is that the government began to take serious actions to protect inhabitants by raising awareness. Such an event will cause laborers to think twice before moving or migrating, which will eventually accelerate growth ${ }^{[12]}$. On the other hand, in Egypt, property rights remained at 40\% until 2012. Moreover, due to the Egyptian revolution in 2011 , it trickled down drastically to $35 \%$ in 2012 . Nevertheless, this caused the country to become unsteady and instigated huge chaos. This may have accelerated labor mobility because workers did not feel safe and were unable to assure a good property. Later on, in 2017, property rights increased to about $40 \%{ }^{[12]}$.

The second pillar in the rule of law is judicial effectiveness, which reflects the capability of judicial or court decisions to be implemented in the most effective possible way to ensure fairness amongst inhabitants.

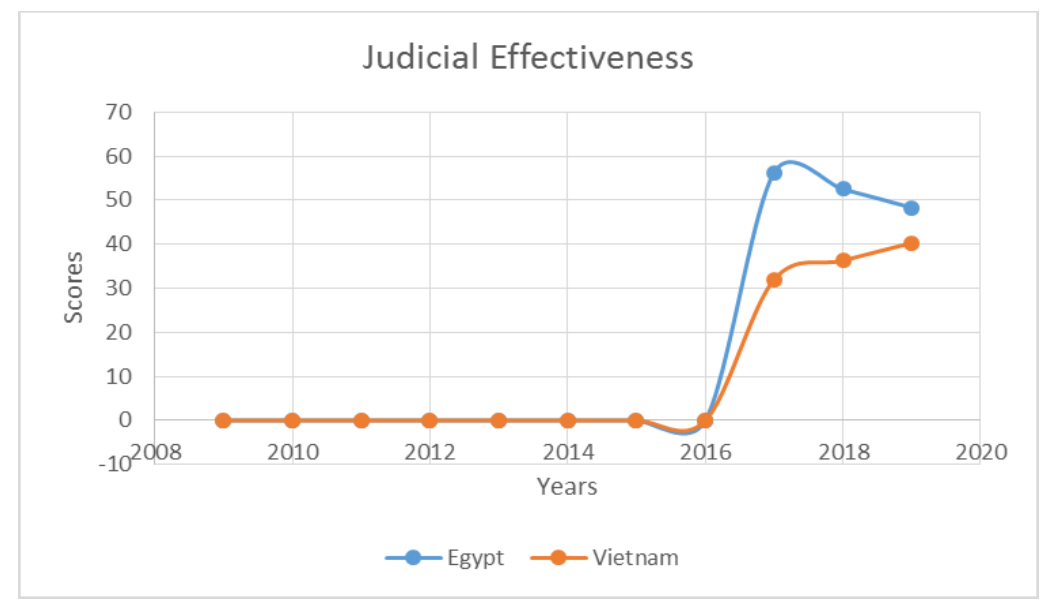

Figure 3. Judicial effectiveness in Egypt and Vietnam (2009-2019)

Source: Heritage Foundation - 2019 Index of Economic Freedom 
Vietnam's judicial system is considered the $86^{\text {th }}$ strongest judicial system, which makes it stronger than Egypt's judicial system. 2017 was the start of a new civil code in Vietnam, which took affect later in the year, showing the increase of the score to about $32 \%$, and later on, throughout the years, reaching its maximum of $40 \%$.

The new civil code has been implemented to protect civil rights and enhance consistency throughout the Vietnamese legal system. This has been beneficial because it exemplifies to the Vietnamese workers that they do not have to migrate as this civil code would ensure and protect them ${ }^{[13]}$.

However, in Egypt, it was different as the scores decreased from 56.3\% to $48.3 \%$ due to the fact that Egypt had difficulties in its government and the modifications in laws. Laborers would then ponder whether to migrate or not due to the fact that the modifications in laws might not be useful or beneficial to them as they are not fixed ${ }^{[14]}$. This figure shows that Egypt is at a higher position than Vietnam despite Egypt's scores keep trickling down while Vietnam's scores continue to rise. This means that they will eventually intersect at some point.

The third pillar in the rule of law is government integrity, which is the arrangement of the government and public organizations, who have values and principles of conduct, to protect the public interest while avoiding chaos. Thus, government integrity can also be observed through the quality of the enforcement of a country's laws and regulations. Chaos is crucial when it comes to government integrity, moreover which foreshadows insecurity and high levels of unemployment.

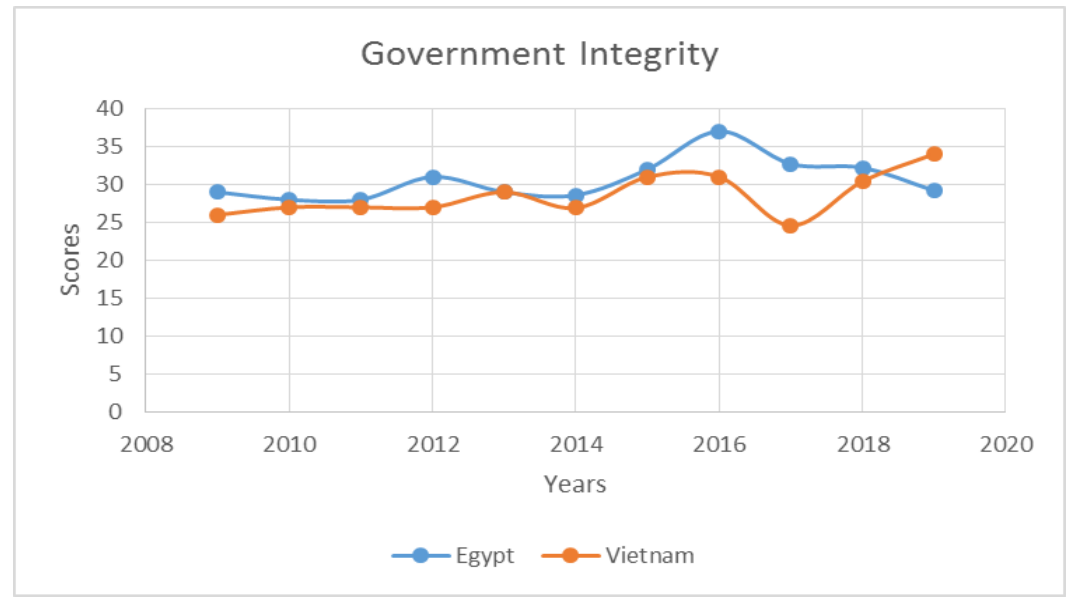

Figure 4. Government integrity in Egypt and Vietnam (2009-2019)

Source: Heritage Foundation - 2019 Index of Economic Freedom

According to Figure 4, there were fluctuations in both Egypt and Vietnam. In 2009, Vietnam's score was about $26 \%$ and at that time, according to the Corruption Perception Index, Vietnam ranked $120^{\text {th }}$. However, in 2019 , Vietnam ranked $96^{\text {th }}$ with a score of $34 \%{ }^{[15]}$. This shows that throughout the years they have attempted to lessen corruption by advocating lenient laws and work efficiency. This is useful for laborers because it would help them to focus more on their jobs while worry less about corruptions and unemployment problems, which might distract them. Egypt also had variations in government integrity scores throughout certain years. In 2009, Egypt's score was around $29 \%$, ranking $111^{\text {th }}$ according to the Corruption Perception Index.

Egypt's score somewhat decreased in 2019, and it is still considered trickling down. Although its' score decreased to about $28 \%$ that year, Egypt's rank rose and became $106^{\text {th }}$. Hence, this shows that there is an ineffective legal system, which is the case in Egypt nowadays. People are not getting enough jobs, and due to other problems, such as monetary expenditures, cause chaos and might eventually lead to workers migrating. Figure 4 exemplifies that Egypt is better than Vietnam in terms of government integrity. 


\section{Government size}

Government spending is the first pillar which represents every country in the universe in regard to the different spending methods according to health, education, etc.

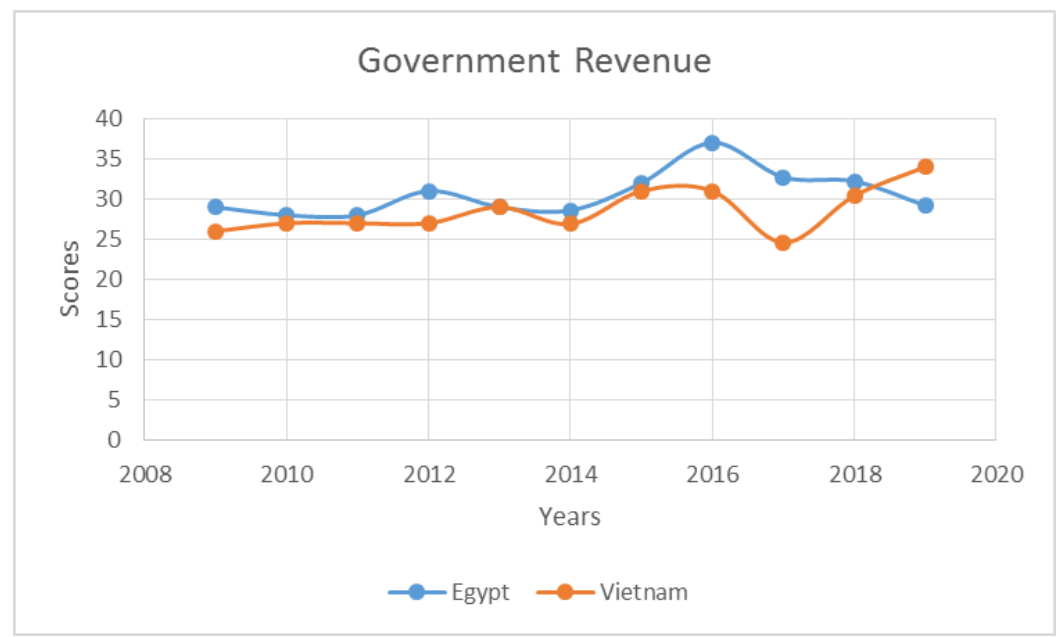

Figure 5. Government spending in Egypt and Vietnam (2009-2019)

Source: Heritage Foundation - 2019 Index of Economic Freedom

Vietnam spends more than a third of their income on entertainment and education while $13 \%$ of it is on utility bills. The government spending in Vietnam is usually around $75 \%$ or somewhat close to that range. The highest was about $80 \%{ }^{[16]}$. This becomes a problem, for instance, if laborers fall sick, they would not be able to guarantee that the government would shift their spending patterns to their own benefit. Moreover, this can ignite a huge spark for migration. Egypt, on the other hand, spends on a lot of things, but mostly on education and health ${ }^{[17]}$. This would give laborers a sense of security, such that if they fall sick from chemicals or equipment while working, the government will then pay for their healthcare. In 2009, Egypt was at $66 \%$, and increased to about $69 \%$ in 2019. Figure 5 shows that Vietnam had a higher spending pattern compared to Egypt.

The second pillar is tax burden which shows the numerous types of tax, such as consumption tax, property, income tax, etc. Taxes are enforced by governments and are paid by individuals.

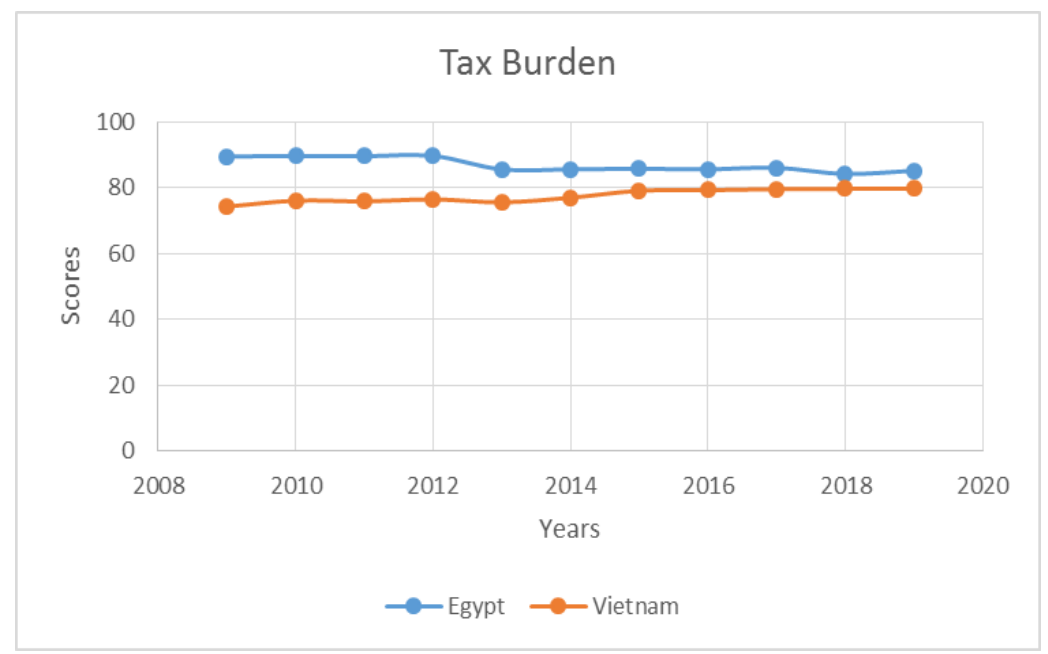

Figure 6. Tax burden in Egypt and Vietnam (2009-2019)

Source: Heritage Foundation - 2019 Index Economic Freedom 
In Vietnam, the residents are paying tax in order for the country to become better. However, there is a downside to it, whereby when taxes become too high, it becomes more of a burden. According to Figure 6, Vietnam's tax was around $77 \%$ to $80 \%$ from 2009 to 2019 , of which the personal income tax there was $35 \%{ }^{[11]}$. Egypt has very high taxes, which makes it a huge burden for its' citizens. This would cause a riot if laborers are not being paid decently while having to pay huge amounts of taxes. Laborers would feel that they are being used and would eventually migrate. According to the figure, tax burdens were slightly fluctuating but were somewhat close to each other. The highest tax rate in Egypt was about 90\%, whereas the highest for Vietnam was $80 \%$. Egypt's personal income tax was $22.5 \%$ in $2019{ }^{[18]}$. The figure exemplifies that the tax burden was higher in Egypt than that in Vietnam. They were somewhat apart during the years from 2009 to 2014. Later throughout the years of 2015 to 2019, they became closer to each other.

The third pillar is fiscal health, which shows that the monetary or expenditure health is enforced by the government for health services and in order for inhabitants to prolong their existence for innovation.

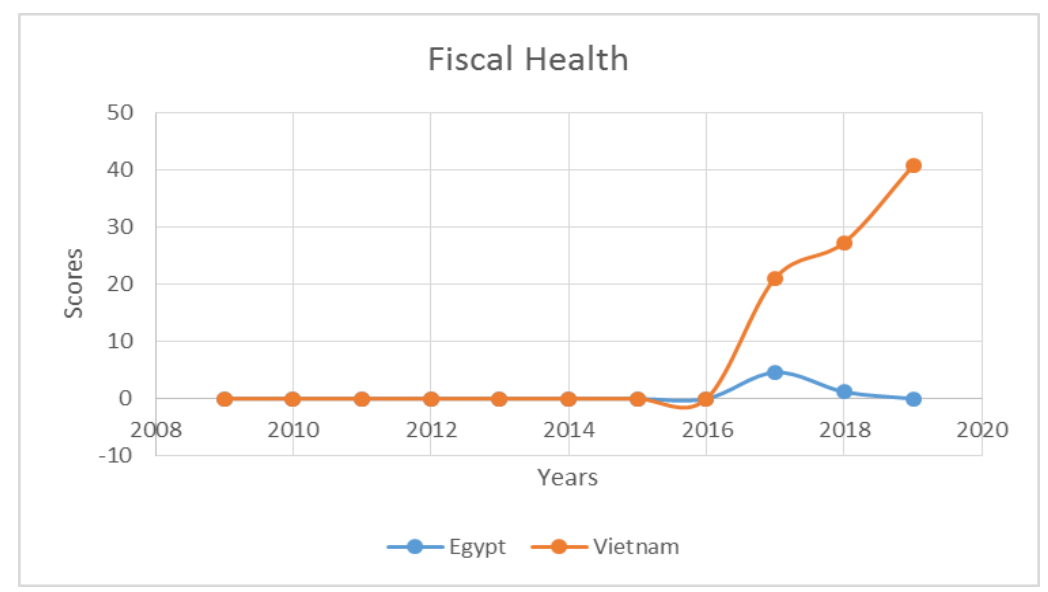

Figure 7. Fiscal health in Egypt and Vietnam (2009-2019)

Source: Heritage Foundation - 2019 Index of Economic Freedom

In Vietnam, the fiscal health increased from 21\% to 41\% from 2017 to 2019, respectively due to the fact that Vietnam has been able to fund its healthcare, which made it more sustainable ${ }^{[19]}$. On the other hand, Egypt's fiscal health was lower than Vietnams'. In 2017, it was $4.6 \%$, and it decreased to $1.2 \%$ in 2018. Hence, this exemplifies that at that period, Egypt had some on-going illnesses. If Vietnam continues to have a sustainable healthcare, workers would not be forced to migrate as they are being taken care of.

\section{Regulatory efficiency}

Business freedom denotes the ability of a person or individual to start a business in a country with certain regulations enforced by the government.

In Vietnam, business freedom somewhat decreased to 59\% from 2015 to 2016. It rose back up to about $61 \%$ in 2017 , and then kept increasing little by little till 2019. The remaining years were somewhat the same. In Egypt, throughout the years, there were changes but the largest was from 2018 to 2019, in which the score dropped from $71 \%$ to $65 \%$.

More business opportunities would pave the way for workers to have better job opportunities, thus unemployment rates would decrease in the future. Figure 8 illustrates that Egypt had higher business freedom than Vietnam. 


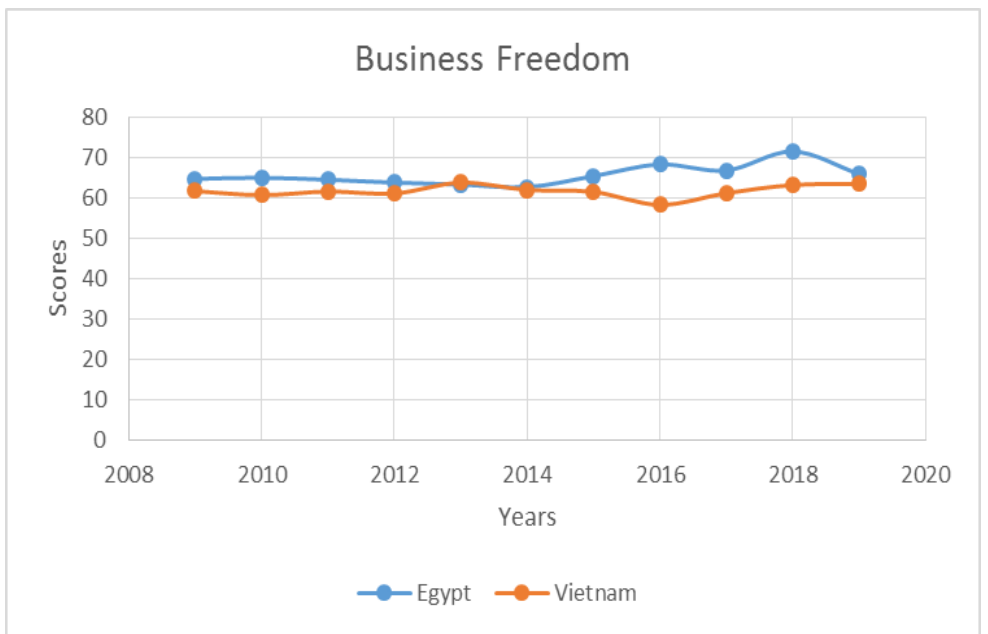

Figure 8. Business freedom in Vietnam and Egypt (2009-2019)

Source: Heritage Foundation - 2019 Index of Economic Freedom

The pillar of labor freedom reflects the diverse regulations made for labor in countries, such as threshold wages.

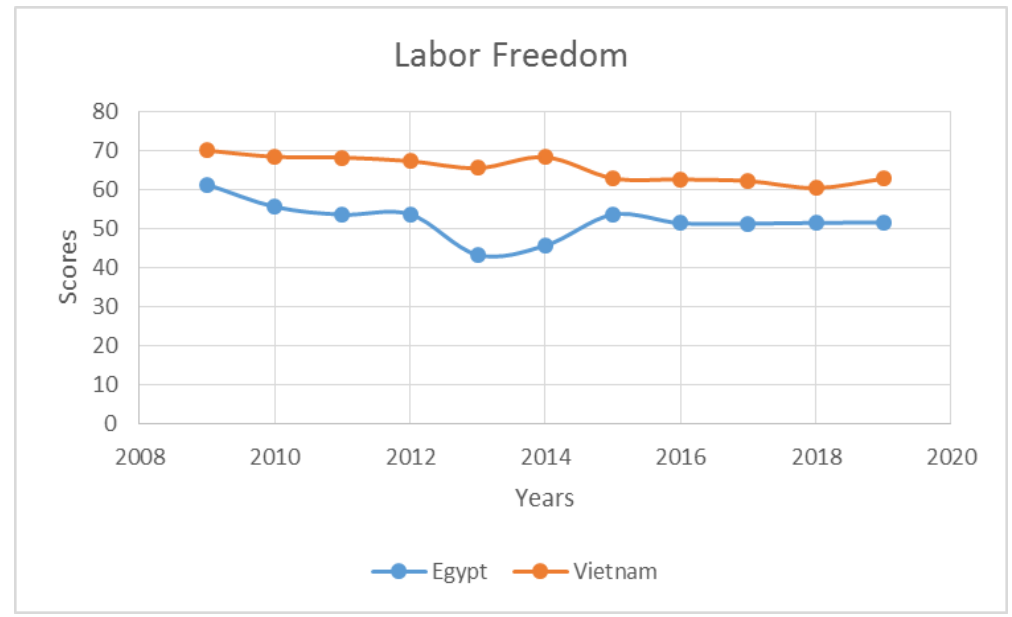

Figure 9. Labor freedom in Egypt and Vietnam (2009-2019)

Source: Heritage Foundation - 2019 Index of Economic Freedom

Vietnam is considered strict in regard to employment contracts ${ }^{[20]}$. If Vietnamese workers feel oppressed and are not as free as they should be, protests might arise, which would cause workers to migrate and in return, this would lead to problems in Vietnam. Vietnam's labor freedom was somewhat stable from 2008 to 2018. This may be an incentive to workers because if they decide to migrate, they are not able to guarantee that they will find a better place to work without any fluctuations.

This is a very strong point in Vietnam which shows that in spite of the fact that it is a strict nation in regard to employment, it is somewhat a stable nation as well. However, a recent study showed that depression has a huge impact on laborers in their likelihood to work. According to Frank and Kessler, based on the National Comorbidity Survey, out of 13 psychiatric disorders, depression has the largest impact on male employment rates ${ }^{[21]}$.

In addition, Eaton and other researchers found that there were high rates of panic and anxiety disorders in laborers who greatly depend on the government ${ }^{[22]}$. The results of the survey showed that psychiatric disorders played an integral role in the number of hours worked per week. Nevertheless, anxiety disorders 
and other sensitive issues displayed high rates of absenteeism ${ }^{[23]}$.

All in all, in spite of the fact that Vietnam displays somewhat stable scores, disorders can play an integral role on the laborers in Vietnam. Throughout the years, the highest score was $70 \%$ while the lowest was $60 \%$. Vietnam had decent scores throughout most years, averaging about $66 \%$. However, in some years, like from 2010 to 2012, the score increased a little to $68 \%$ whereas in 2013 , it decreased to about $67 \%$. In 2014, it increased again, and then throughout 2014 to 2018, the scores remained somewhat the same. Finally, in 2019, it increased to $62 \%$. This exemplifies that Vietnam had very small fluctuations in its labor freedom, which explains that they were somewhat stable. This is quite the opposite in Egypt.

Egypt had certain fluctuations at specific periods. In 2009, the score was $60 \%$, then in 2010 , it decreased to 56\%. Until 2012, the scores were around 56\%. However, in 2012 to 2015, the Egyptian labor freedom score exhibited fluctuations, where in 2012, the score was $52 \%$ and in 2013 , it decreased greatly to $42 \%$. In 2014 and 2015, the scores were $47 \%$ and 52\%, respectively. The reason for these variances is that workers were trying to secure and guarantee their rights ${ }^{[24]}$. This was due to the fact that workers were working long hours without rest periods, and they were paid minimal wages.

This issue is very common in Egypt because the government neglects the workers and does not provide proper rights. An example is the January 25 Revolution, which exhibited how laborers and the youth were disappointed with the government and protested in Tahrir Square. The protests and riots toward the government officials continued until the Egyptians achieved what they had desired. Egyptians are considered very demanding, and they do not settle for less. Throughout the years, from 2016 to 2019, the scores became somewhat stable in spite of the fact that Egypt still continues to have governmental and presidency issues to this very day. The last year recorded was in 2019, in which the score was 51\%.

Figure 9 shows that Vietnam had better labor freedom scores than Egypt throughout the years.

The pillar of monetary freedom joins a proportion of price stability with evaluation of price controls.

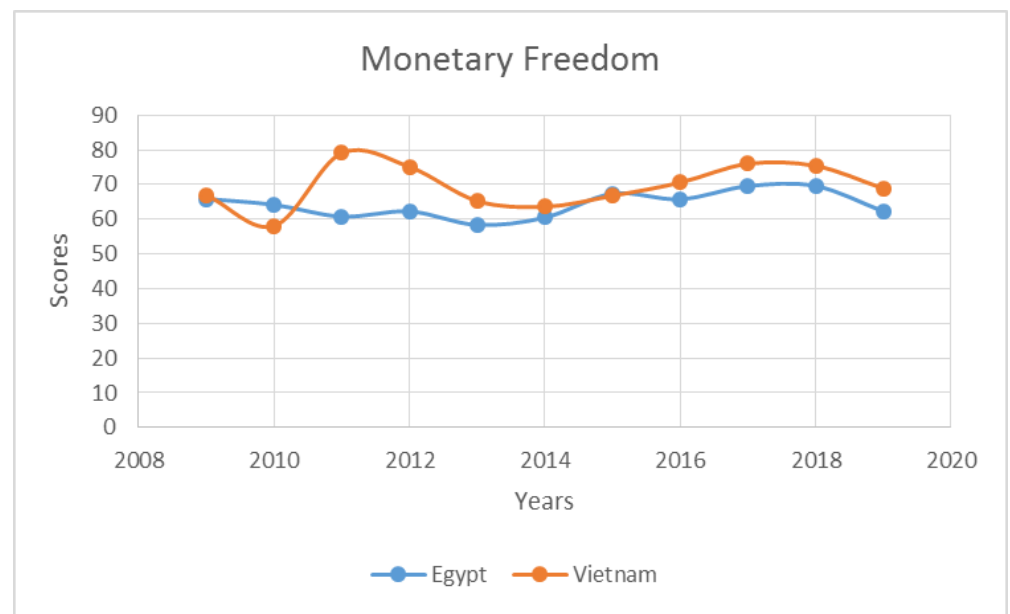

Figure 10. Monetary freedom in Egypt and Vietnam (2009-2019)

Source: Heritage Foundation - 2019 Index of Economic Freedom

Vietnam had a lot of fluctuations throughout the years, from 2009 to 2019. The highest fluctuation was from $59 \%$ to $80 \%$ in 2010 to 2011 . The government tightened the price controls for air travel, energy, utilities, natural resources, pharmaceuticals, education, healthcare, and some housing in 2018 to fight the inflation ${ }^{[11]}$. The highest and lowest points were $80 \%$ and $59 \%$, respectively.

Meanwhile, Egypt had some fluctuations, but they were not the same as Vietnam's. According to Figure 10, in 2015, its' score rose to about $67 \%$ because of certain monetary policies which aided in boosting the economic growth. Boosting the economic growth would also create better job opportunities for laborers. All in all, Vietnam's score was higher than that of Egypt's in respect to monetary freedom. 


\section{Open markets}

The first pillar in the open market is the trade freedom, which is a complex measure of the absence of tariff and non-tariff barriers that affect imports and exports of goods and services. The trade freedom score is based on two inputs: the trade-weighted average tariff rate and non-tariff barriers ${ }^{[11]}$.

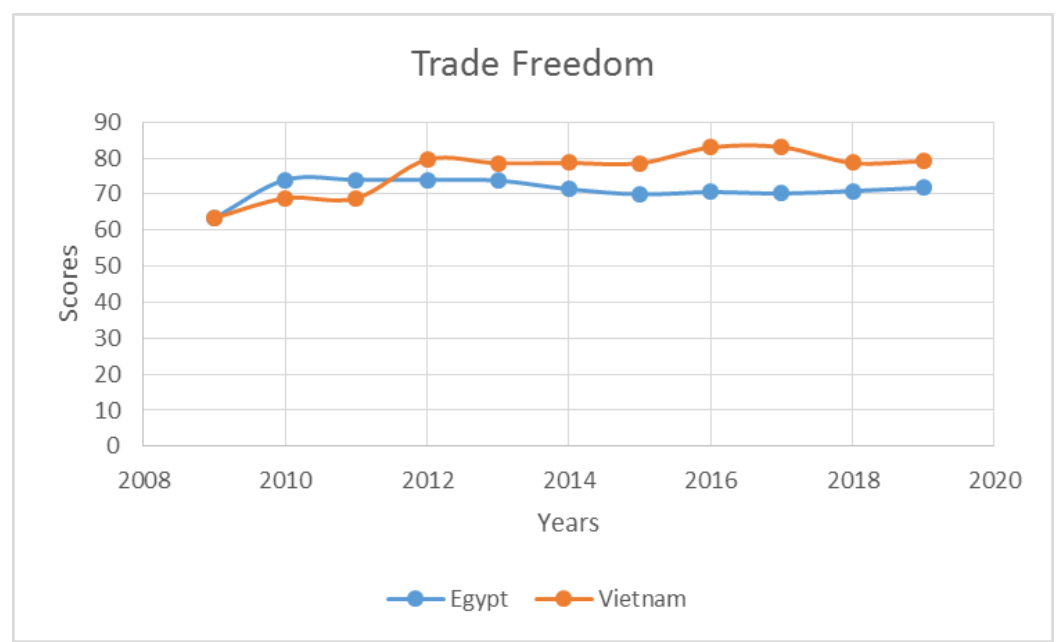

Figure 11. Trade freedom in Egypt and Vietnam (2009-2019)

Source: Heritage Foundation - 2019 Index of Economic Freedom

Vietnam's trade score rose from $69 \%$ to $80 \%$ in 2011 to 2012 . However, in the following years, the fluctuations were not stable, usually between $81 \%$. If trade imports and exports increase, there are more job opportunities. Most of the scores are in the freelance as well as in 2016 and 2017, they are in the freelance [11]. In Egypt, there were some changes but not huge fluctuations, except from 2009 to 2010 due to increased trades, which increased job opportunities. However, in 2011, during the revolution, everything collapsed including labor mobility, in which it started to trickle. The youth protested for their rights and chaos occurred immensely. In spite of that, the trade flowed freely and there were no contingencies. The lowest point was $61 \%$ whereas the highest was $72 \%{ }^{[11]}$.

The second pillar is investment freedom, which shows the ability to entice other countries and convince them to invest although there are limitations made for the investors.

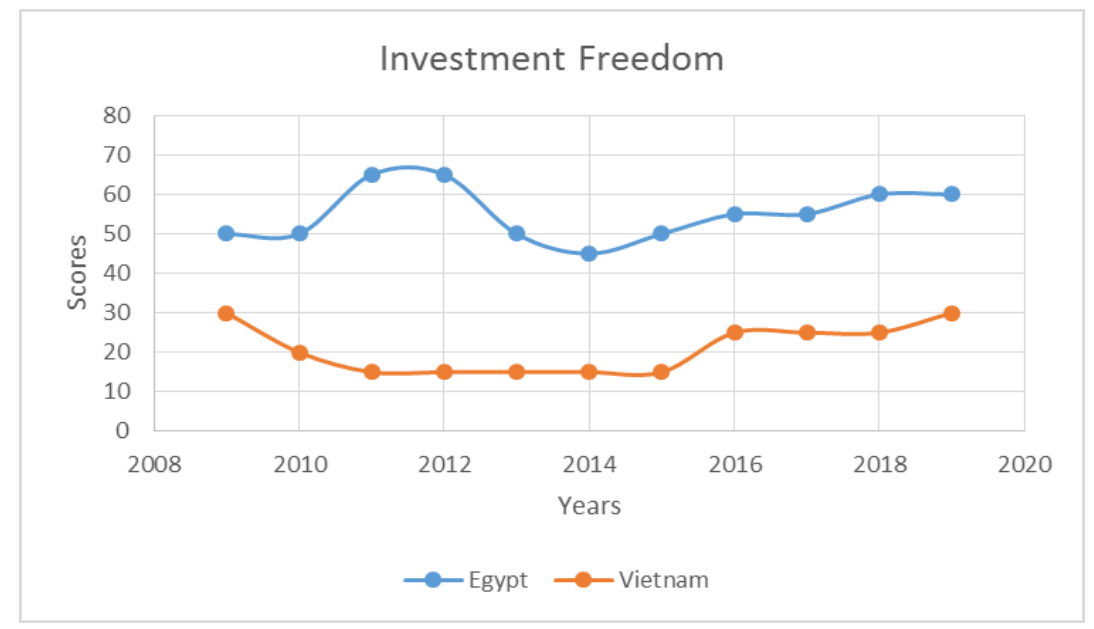

Figure 12. Investment freedom in Egypt and Vietnam (2009-2019)

Source: Heritage Foundation - 2019 Index of Economic Freedom 
Investments decreased in Vietnam from 30\% in 2009, which then rose again from 2016 onwards due certain reasons: Vietnam's FDI (foreign direct investment) inflow in 2018 was around USD 15.50 billion, which was an upsurge from the year before (USD 14.10 billion in 2017), while the total FDI stock extended to USD 145 billion in 2018 according to the United Nations Conference on Trade and Development's (UNCTAD's) 2019 World Investment Report. Inflows are probable to carry on, ratifying the country's situation as one of the most enticing nations in regard to FDI in Asia.

Egypt, on the other hand, faced some political issues due to the June 30 Revolution, which foreshadowed a huge decrease. Numbers trickled down from as high as $66 \%$ to as low as $50 \%$ throughout the years, from 2011 to 2013 . However, as time passed by, it increased due to new job opportunities, which caused workers to migrate and mobilize. Egypt did not reach its high peak of $65 \%$ but increased to $60 \%$ in 2019. Hence, this shows that Egypt had more investments than Vietnam which made it better during certain times.

The third pillar is financial freedom which generally means having enough savings, investments, and cash on hand to afford the lifestyle we want for ourselves and our families.

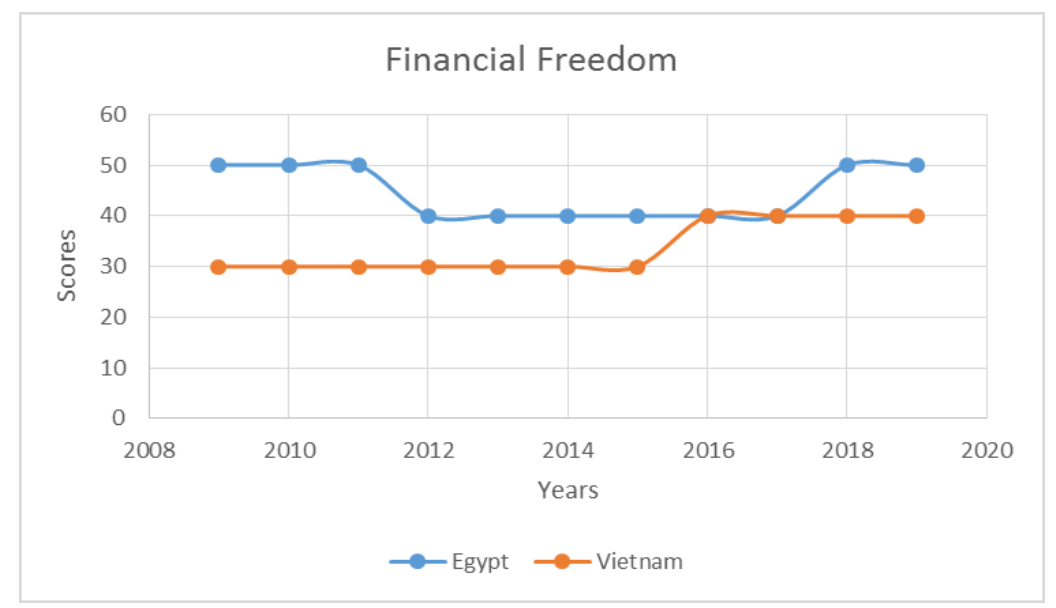

Figure 13. Financial freedom in Egypt and Vietnam (2009-2019)

Source: Heritage Foundation - 2019 Index of Economic Freedom

This demographic exemplifies that Vietnam's financial freedom increased from 30\% to 40\% from 2015 to 2016. More money flowed inside, and people were able to invest and live the life they desired. In the following years, the scores did not increase but remained as stable as possible, finishing in 2019 with $40 \%$. Egypt has had some rough times, and this explains a lot because in 2011 to 2012, there was a decrease from $50 \%$ to $40 \%$, which showed that the revolution had a huge impact on people's lives and how they were unable to afford or live the life they desired due to chaos and corruption. Egypt remained about $40 \%$ till 2017 when it started to increase, and it reached 50\% again. All in all, a better financial situation at hand would not force workers to migrate as they would be satisfied being where they are.

\section{Conclusion}

This research paper tackled and discussed the effect of labor mobility on economic growth in both Egypt and Vietnam from 2009 to 2019. Evidence was provided by graphs and demographics, illustrating and exemplifying the pillars of growth and their roles toward both countries. Firstly, Egypt had higher scores in terms of property rights, judicial effectiveness, government integrity, business freedom, investment freedom, and financial freedom. Vietnam had higher scores in the others: government spending, fiscal health, tax burden, labor freedom, monetary freedom, and trade freedom. 
In spite of Egypt having higher overall scores than Vietnam in most years, it had a lower rank according to the Heritage Foundation. Vietnam ranked $128^{\text {th }}$ with a score of $55.3 \%$ whereas Egypt ranked $144^{\text {th }}$ with a score of 52.5\%. Egypt needs to decrease its tax burden and try as much as possible to increase the growth pillars of government spending, fiscal health, labor freedom, monetary freedom, and trade freedom. In terms of government spending, the Egyptian government needs to figure out how they can efficiently and effectively spend to improve in education and health; the two most important aspects in a country. Fiscal health implies that a nation should be aware that whenever a person falls ill, immediate action is required to prevent the disease from spreading. Labor freedom workers need to be given breaks, for example working 10 to 12 hours with a break, in order for them not to feel as if they are incarcerated. Inflation and outburst must be controlled in order for Egypt to avoid an economic breakdown. Lastly, Egypt needs to increase exports by developing and enhancing the products.

In regard to Vietnam, the residents should be given rights in granting them their rights to property, such as lands or buildings. Juries must be held responsible for their actions, and they should always ensure that only fair laws are enforced in order to ensure a fair society. Governments and political parties need to try as much as possible to reduce corruption and mischief while promoting or increasing productivity. Business freedom needs to be solved by dealing with land regulations. Vietnam needs to find a way to attract investors to invest in the nation. This will only happen if it is a stable nation. Lastly, there must be liberation from government oppressors to increase financial freedom.

According to the demographics provided by the Heritage Foundation, both Egypt and Vietnam had different scores in regard to the pillars of growth. There were 12 pillars involved, and each one gave a rather different score than the other. The overall score showed that Egypt was substantially higher than Vietnam except from 2018 to 2019. The reason behind such decrease is that Egypt has governmental presidency issues, and its economy is in a bad state, in which Egypt is still trying to solve these issues even to this day.

The first pillar of growth is property rights, and according to the Heritage Foundation, Egypt had higher scores from 2009 to 2016, whereas from 2017 to 2019, Vietnam had higher scores. In terms of judicial effectiveness, Egypt scored higher than Vietnam during those 3 years. Government integrity had many fluctuations, but Egypt had the upper hand in most years. Egypt displayed higher scores in regard to tax burden, however Vietnam had higher scores in terms of government spending and fiscal health. On the other hand, Egypt displayed a higher score in business freedom compared to Vietnam whereas Vietnam had the upper hand in labor, monetary, and trade freedom. Lastly, Egypt had higher scores compared to Vietnam in investment and financial freedom.

\section{Disclosure statement}

The author declares that there is no conflict of interest.

\section{References}

[1] Worldometer, 2020, Population by Country. https://www.worldometers.info/worldpopulation/populati on-by-country/ (updated August 11, 2020).

[2] OECD S, Outlook E, 2005, Organization for Economic Cooperation and Development Publishing. https://oec.world/en/profile/country/egy/

[3] Trading economics, 2020, Vietnam's Percent of Firms Using Technology Licensed from Foreign Companies. https://tradingeconomics.com/vietnam/percent-of-firms-usingtechnology-licensed-fromforeign-companies-wb-data.html

[4] Justesen MK, 2008, The Effect of Economic Freedom on Growth Revisited: New Evidence on Causality from a Panel of Countries 1970-1999. European Journal of Political Economy, 24(3): 642- 
60.

[5] World Bank, 2005, The World Bank Annual Report 2005, The World Bank, Washington, DC, 3.

[6] Calmfors L, Driffill J, 1988, Bargaining Structure, Corporatism and Macroeconomic Performance. Economic Policy, 3(6): 13-61.

[7] Abowd JM, Freeman RB, 1988, Immigration, Trade, and the Labor Market, National Bureau of Economic Research.

[8] De Haan J, Lundström S, Sturm JE, 2006, Market-Oriented Institutions and Policies and Economic Growth: A Critical Survey. Journal of Economic Surveys, 20(2): 157-91.

[9] Barro RJ, 1997, Determinants of Economic Growth, MIT Press, Cambridge, MA.

[10] Briault C, 1995, The Cost of Inflation, Bank of England Quarterly Bulletin, 1-11.

[11] Country Rankings, 2019 Index of Economic Freedom. The Heritage Foundation. https://www.heritage. org/index/ranking (accessed on February 28, 2020).

[12] Newman C, Tarp F, Van Den Broeck K, 2015, Property Rights and Productivity: The Case of Joint Land Titling in Vietnam. Land Economics, 91(1): 91-105.

[13] Hosny A, Kandil M, Mohtadi H, 2013, The Egyptian Economy Post-Revolution: Sectoral Diagnosis of Potential Strengths and Binding Constraints. Working Papers 767, Economic Research Forum. https://ideas.repec.org/p/erg/wpaper/767.html

[14] 2017, A Look at Vietnam's Legal System. Oxford Business Group. https://oxfordbusinessgroup.com/o verview/law-land-look-country\%E2\%80\%99s-legal-system

[15] Auf Y, 2018, The Battle Over Appointing Judges in Egypt. Carnegie Endowment for International Peace. https://carnegieendowment.org/sada/75274

[16] 2020, Corruption Perception Index. https://www.transparency.org/research/cpi/overview

[17] Nguyen D, 2018, Vietnamese Spend Most of Their Income on Food and Drinks. VN Express. https://e.vnexpress.net/news/business/data-speaks/vietnamese-spend-most-of-their-income-on-foodand-drinks-3832981.html

[18] 2018, Egypt Implements 2018/19 Budget with More Expenditures on Health, Education. Ahram Online. http://english.ahram.org.eg/NewsContent/3/12/305965/Business/Economy/Egypt-implements --budget-with-more-expenditures-on.aspx

[19] 2019, Egypt Personal Income Tax Rate. Trading Economics. https://tradingeconomics.com/egypt/pers onal-income-tax-rate

[20] Pekerti A, Vuong QH, Manh HT, et al., 2017, Health Care Payments in Vietnam: Patients' Quagmire of Caring for Health versus Economic Destitution. Int J Environ Res Public Health, 14(10): 1118. https://www.ncbi.nlm.nih.gov/pmc/articles/PMC5664619/

[21] 2011, Vietnam's Employee-Friendly Labor Laws. Fisher Phillips. https://www.fisherphillips.com/Cros s-Border-Employer/Vietname28099s-Employee-Friendly-Labor-Laws

[22] Ettner SL, Frank RG, Kessler RC, 1997, The Impact of Psychiatric Disorders on Labor Market Outcomes. Industrial and Labor Relations, Sage Publications, Inc., 51(1): 66-81.

[23] Eaton WDA (eds) 1991, Panic and Phobia, in Psychiatric Disorders in America, Robins L, Reiger D.

[24] French MT, 1998, Mental Health, Absenteeism, and Earnings at a Large Manufacturing Worksite. The Journal of Mental Health Policy and Economics, : 161-72.

[25] 2017, Everything you Need to Know About Egypt's Labor Law. WUZZUF Blog. http://blog.wuzzuf.ne t/2017/11/13/egypt-labor-law/ 